\title{
LABOUR DEMAND IN GERMANY: AN ASSESSMENT OF NON-WAGE LABOUR COSTS
}

\author{
YU-Fu CHEN \\ MICHAEL FUNKE
}

CESIFO WORKING PAPER No. 952

CATEGORY 4: LABOUR MARKETS

MAY 2003

- from the CESifo website: www.CESifo.de 


\title{
LABOUR DEMAND IN GERMANY: AN ASSESSMENT OF NON-WAGE LABOUR COSTS
}

\begin{abstract}
The data indicate that non-wage labour costs in Germany have reached a record high in recent years. From 1972 to 2001, the ratio of non-wage labour costs to direct compensation in West German manufacturing industry rose from 55.6 per cent to 81.2 per cent. The topic of nonwage labour costs is increasingly being discussed among and between the political parties because non-wage labour costs are likely to have major negative effects on employment. We follow the real options approach, which allows us to investigate the value to a firm of waiting to adjust labour when the firm's revenues are stochastic and adjustment costs are sunk. Simulation exercises show that the interaction between hiring and firing costs, non-wage labour costs and uncertainty can have important ramifications for employment dynamics.
\end{abstract}

JEL Code: D81, J23, J31, J32.

Keywords: real options, labour demand, non-wage labour costs, hiring and firing costs, Germany.

$\mathrm{Yu}-\mathrm{Fu}$ Chen

Department of Economic Studies

University of Dundee

Dundee DD1 4HN

Great Britain

y.f.chen@dundee.ac.uk
Michael Funke

Department of Economics

Hamburg University

Von-Melle-Park 5

20146 Hamburg

Germany

funke@hermes.econ.uni-hamburg.de 


\section{Introduction}

Non-wage labour costs are the subject of intensive political debate. Payroll taxes drive a wedge between the cost of a worker to an employer and the wage received. If wages and prices are relatively flexible, high non-wage labour costs are unlikely to have major negative effects on employment in the long-run. However, in countries where wages and pric es are inflexible, employment will suffer if nonwage labour costs increase. Many of the job losses will fall on low-paid workers, due among other things to the existence of binding wage floors such as legal or collectively-bargained minimum wages. Increasing non-wage labour costs also tend to encourage substitution away from labour to more capital-intensive methods of production. Therefore, reducing social insurance contributions ranks high on the German political agenda. ${ }^{1}$

Non-wage labour costs are those categories of the enterprise's total labour costs comprising other than direct compensation. Non-wage labour costs account for a very substantial and rising proportion of total labour costs. There are several ways of defining non-wage labour costs. The annual analysis of non-wage labour costs in Germany by the "Institut der deutschen Wirtschaft" is based on official statistics from the Federal Statistical Office in Wiesbaden, which conducts surveys on labour costs every four years. The official statistics distinguish between compensation for hours actually worked and non-wage labour costs. Non-wage labour costs are differentiated into pay for days not worked, special payments, statutory social welfare costs and other non-wage labour costs. The statistics differentiates between statutory non-wage labour costs, and non-statutory costs resulting from collective bargaining and additional benefits provided by the employer. ${ }^{2}$ Table 1 below sets out the latest aggregate data on the development of wage and non-wage labour costs in West German manufacturing industries [see Schröder (2002a)].

Table 1: Annual Labour Costs in West German Manufacturing Industry per Employee in $€$

\begin{tabular}{|l|l|l|l|l|l|l|l|l|l|l|l|l|}
\hline $\begin{array}{l}\text { Direct } \\
\text { Compensation }\end{array}$ & 7535 & 9600 & 11557 & 13616 & 15406 & 17580 & 21314 & 24218 & 25000 & 26455 & 27025 \\
\hline $\begin{array}{l}\text { Non-Wage } \\
\text { Labour Costs }\end{array}$ & 4188 & 6304 & 8099 & 10276 & 12198 & 14149 & 17139 & 19852 & 20450 & 21505 & 21940 \\
\hline $\begin{array}{l}\text { Share of Non- } \\
\begin{array}{l}\text { Wage Labour } \\
\text { Costs in \% }\end{array}\end{array}$ & 55.6 & 65.7 & 70.1 & 75.5 & 79.2 & 80.5 & 80.4 & 82.0 & 81.8 & 81.3 & 81.2 \\
\hline
\end{tabular}

\footnotetext{
${ }^{1}$ Over the last decade, Germany appeared to be unable to reform labour market institutions and the welfare state in order to reduce high and rising unemployment rates. In this respect it forms an unholy triple alliance of reform laggards with France and Italy [see Minford and Naraidoo (2002)].

${ }^{2}$ However, one should bear in mind that some non-statutory non-wage labour costs - such as holidays - may result from the implementation of labour law and additional collective agreements by the social partners. To a certain extent these kinds of costs might also be attributed to statutory non-wage labour costs.
} 
In West German manufacturing industry, non-wage labour costs reached an all-time high of $€ 21940$ in $2001 .^{3}$ From 1972 to 2000 , the ratio of non-wage labour costs to direct compensation grew by 25.6 percentage points to $81.2 \%$. For 2003 , a further rise in non-wage labour costs is predicted. In January 2003 , the contribution rates for all types of social insurance were raised again and a further increase of statutory social welfare contributions of employers is expected for 2004. This means uncertainty for firms about whether and, if so, when a further increase is to be expected.

The disaggregate data in Table 2 indicate that the rise of non-wage labour costs from 1992 to 2001 can be attributed to increases in both the statutory and the non-statutory elements. A special role is played by the increases in the costs of social security contributions, which rose at a significantly higher rate in the East than in the West. Furthermore, increases in costs caused by sick pay, and holidays and holiday payments, were of importance.

Table 2: Non-Wage Labour Costs in Manufacturing Industry as \% of Direct Compensation

\begin{tabular}{|l|l|l|l|l|}
\hline & \multicolumn{2}{|c|}{ West Germany } & \multicolumn{2}{c|}{ East Germany } \\
\hline Statutory Non-Wage Labour Costs & $\mathbf{1 9 9 2}$ & $\mathbf{2 0 0 1}$ & $\mathbf{1 9 9 2}$ & $\mathbf{2 0 0 1}$ \\
\hline Employer's Contribution to Social Security & 35.4 & 37.1 & 34.6 & 37.8 \\
\hline Paid Public Holidays & 25.4 & 28.4 & 26.2 & 28.9 \\
\hline Sickness Payments & 4.5 & 5.0 & 3.7 & 4.6 \\
\hline Other Statutory Allowances & 5.1 & 3.3 & 3.9 & 3.2 \\
\hline Non-Statutory Non-Wage Labour Costs & 0.4 & 0.4 & 0.8 & 1.1 \\
\hline Holiday Payments & 45.0 & 44.1 & 31.7 & 30.5 \\
\hline Special Payments & 19.3 & 18.6 & 13.6 & 15.4 \\
\hline Pension Schemes & 9.2 & 8.3 & 3.9 & 4.0 \\
\hline CapitalForming Payments & 7.4 & 7.7 & 0.7 & 1.7 \\
\hline Other Non-Wage Labour Costs & 1.3 & 1.1 & 0.1 & 0.4 \\
\hline Total Non-Wage Labour Costs & 7.8 & 8.4 & 13.4 & 9.0 \\
\hline
\end{tabular}

Source: Schröder (2002a); the calculations are based on compensation for hours actually worked.

Table 3 indicates that there is significant variation in non-wage labour costs across countries. Hourly labour costs in West German manufacturing amounted to $€ 26.16$ in 2001 . This was $27 \%$ above the average of countries compared. A great deal of this difference was due to non-wage labour costs ( $€$ 11.72 per hour) which were 54\% above average in Germany. Given this evidence, there is widespread agreement among the employers and the main political parties that non-wage labour costs are "far too high" and have to be reduced because they drive up labour costs and thus reduce the demand for labour. Firms also claim that uncertainty about the future level of non-wage labour costs is an impediment to job creation. Therefore, they form expectations and beliefs on the future behaviour of the driving economic variables, which cannot be predicted with certainty. The modelling framework

\footnotetext{
${ }^{3}$ In East German manufacturing industry, annual direct compensation (non-wage labour costs) reached $€ 18825$ $(€ 12855)$ in 2001 and therefore the share of non-wage labour costs reached $68.3 \%$ of total compensation. Though rising, non-wage labour in eastern Germany were still lower than in western Germany. The differences result from less generous fringe benefits such as vacation and supplementary pension schemes.
} 
has to account for this distinct challenge and has to formalise this issue in a coherent economic model. ${ }^{4}$

Table 3: International Comparison of Hourly Wages in the Manufacturing Industry (2001, in €)

\begin{tabular}{|c|c|c|c|}
\hline & Direct Hourly Wages & Non-Wage Labour Costs & $\begin{array}{l}\text { Share of Non-Wage } \\
\text { Labour Costs in \% }\end{array}$ \\
\hline Austria & 10.90 & 10.10 & 93 \\
\hline Belgium & 11.84 & 11.31 & 96 \\
\hline Canada & 13.07 & 4.97 & 38 \\
\hline Denmark & 19.58 & 4.91 & 25 \\
\hline East Germany & 10.09 & 6.76 & 67 \\
\hline Finland & 12.51 & 9.61 & 77 \\
\hline France & 9.89 & 9.03 & 91 \\
\hline Greece & 5.27 & 3.59 & 68 \\
\hline Ireland & 11.47 & 4.54 & 40 \\
\hline Italy & 8.14 & 7.77 & 96 \\
\hline Japan & 13.13 & 9.09 & 69 \\
\hline Netherlands & 12.18 & 9.80 & 80 \\
\hline Norway & 17.12 & 8.22 & 48 \\
\hline Portugal & 3.79 & 2.96 & 78 \\
\hline Spain & 8.01 & 6.67 & 83 \\
\hline Sweden & 12.35 & 8.56 & 69 \\
\hline Switzerland & 16.37 & 8.59 & 53 \\
\hline UK & 13.41 & 5.82 & 43 \\
\hline US & 16.57 & 6.42 & 39 \\
\hline West Germany & 14.44 & 11.72 & 81 \\
\hline
\end{tabular}

Orthodox theory suggests to calculate the net present value (NPV) of a mooted employment decision. When the present value of future profits is bigger than the present value of the costs of hiring a worker - that is, the $N P V$ is positive - then go ahead. All employment calculations therefore rely on predicting uncertain future profits. But the traditional theory also assumes, implicitly, that employment decisions are a now-or-never choice. In many circumstances this is unrealistic and waiting offers a valuable chance to learn more about the likely fate of the decision. The ability to delay a partially irreversible employment decision is like a financial "call option". The firm has the right, but not the obligation, to buy (hire) a security (new employees) at a specified price (the hiring cost) at a future time of its choosing. This option has a value. When the firm makes the investment it exercises (or, in financial jargon, "kills") its option. It follows then, that the cost of that "killed" option (the value of waiting for better information) ought to be included when calculating the $N P V$. Before a hiring decision goes

\footnotetext{
${ }^{4}$ An interesting feature is that some European countries succeeded to restore lower rates of unemployment in the 1990s despite a high share of non-wage labour costs. A remarkable example for the way out of Europe's labour market misery are the Netherlands. The Dutch employer associations and unions reached a historic agreement on wage moderation (the so-called Wassenaar Agreement) in 1992. It turned out that wage moderation was an essential ingredient of the Dutch success story. The Dutch experience is consistent with the well-known humpshaped relationship between the degree of bargaining coordination and the real wage level of Calmfors and Driffill (1988) saying that labour markets work best in those countries with either very decentralised or very centralised wage formation systems.
} 
ahead, the present value of future profits should exceed the hiring costs by at least the value of keeping the real option alive. ${ }^{5}$ In other words, real options are directly analogous to a traditional American call option. ${ }^{6}$ While real options are similar, the primary distinction is the non-financial nature of the underlying asset being acquired. ${ }^{7}$

Against this background, the paper proceeds as follows. The application of the real options approach to employment determination is sketched in section 2. Section 3 discusses the simulation results. A summary and some policy conclusions are provided in section 4. Additional appendices provide technical results used in the body of the paper.

\section{Labour Demand and Non-Wage Labour Costs in a Real Options Framework}

In valuing real options, one inevitably faces a trade-off between the analytical and computational tractability, and the complexity of the underlying model. In the light of this trade-off, academic economists have found it convenient to impose sufficient structure on the model to give closed-form solution. Following this strategy, we consider a representative firm facing constant returns to scale CES production function

$$
Y=\left[\theta K^{-\mu}+(1-\theta) L^{-\mu}\right]^{-1 / \mu}
$$

where $Y$ denotes output, $-1<\mu<\infty$ is the substitution parameters $(\mu \neq 0), 0<\theta<1$ is the distribution parameters, $L$ is the number of employees, and $K$ is the capital stock. We allow for imperfect competition, i.e. we assume that the firm faces an isoelastic demand function

$$
p=Y^{(1-\psi) / \psi} Z, \psi \geq 1
$$

where $p$ represents the price, $Z$ denotes the demand shock, and $\psi$ is an elasticity parameter that takes its minimum value of 1 under perfect competition [see, Abel and Eberly (1994)]. Therefore, current profits, measured in units of output, are defined as,

\footnotetext{
${ }^{5}$ In fact, that is usually happening in practice. Firms calculate the $N P V$, but discount predicted profits using a „hurdle“ required rate of return which is much higher than the standard discount rate to account for the uncertainty underlying the project. Applying traditional options-pricing theory to employment decisions leads to the conclusion that such hurdle rates are perfectly sensible. However, the real options theory allows firms to set them on a more rational basis than gut instinct.

${ }^{6}$ A European option can only be exercised on the expiration date whereas an American option can be exercised at any time up to and included the expiration date.

7 The analogy arises because labour adjustment costs are at least partially sunk. Real option theory therefore provides an extremely useful method of unlocking the value in employment decisions. The real options literature
} 


$$
\Pi=Z\left[\theta K^{-\mu}+(1-\theta) L^{-\mu}\right] \frac{-1}{\mu \psi}-w(1+\tau) L
$$

where $\tau$ denotes the ratio of non-wage labour costs and $w$ is real wage. To keep the model simple we abstract from taxes. The representative risk-neutral firm maximises its discounted flow of profits

$$
V=\max _{L} \int_{0}^{\infty}\left[z\left[\theta K^{-\mu}+(1-\theta) L^{-\mu} \frac{-1}{\mu \psi}-w(1+\tau) L\right] e^{-r s} d s\right.
$$

where $V$ denotes the intertemporal profit function and $r$ is the real interest rate. To evaluate the impact of non-wage labour costs upon labour demand, it is necessary to recognise that production and employment are inherently dynamic and uncertain processes. We therefore assume that the stochastic demand factor $Z$ follows the geometric Brownian motion

$$
d Z=\eta Z d t+\sigma Z d \Phi
$$

where $\bar{\Phi}$ is a Wiener process, $d \bar{\Phi}=\varepsilon \sqrt{d t}$ (since $\varepsilon$ is a normally distributed random variable with mean zero and a standard deviation of unity), $\eta$ is the drift term and $\sigma$ is the variance parameter. Thus, we have an optimal stopping problem - we must determine when it is optimal to hire or fire workers, given the stochastic evolution of $Z$. Additionally, it is assumed that the payroll tax $\tau$ follows the jump processes

$$
d \tau=d J_{1}+d J_{2}
$$

where $d J_{1}$ and $d J_{2}$ are the increments of Poisson processes (with mean arrival rates $\lambda_{1}$ and $\lambda_{2}$ ). It is assumed that if an "event 1" (“event 2") occurs, $\tau$ increases (falls) by $\phi_{1}\left(\phi_{2}\right)$ percent with probability $1 .^{8}$ Over each time interval $d t$ there is a probability $\lambda_{1} d t$ (or $\lambda_{2} d t$ ) that it will rise (drop) by $\phi_{1} \tau\left(\phi_{2} \tau\right)$. Additionally, we assume that $\left(d J_{1}, d J_{2}\right)$ and $d \bar{\omega}$ are independent to each other, i.e. $E\left(d \Phi d J_{1}\right)=0$,

is too vast to survey here. Excellent surveys are provided by Amran and Kulatilaka (1999), Copeland and Antikarov (2001), Coy (1999), Dixit and Pindyck (1994) and Lander and Pinches (1998).

${ }^{8}$ Given the high level of unemployment, the German government has implemented an environmental tax reform in several stages since 1999 and has used the proceeds to cut employer and employees contributions to the pension fund. This policy-induced fall of non-wage labour costs may be represented by „event 2“ in equation (6). Environmental taxation is often seen as an attractive solution for cutting unemployment. Such a reform may yield a „double dividend“: not only an improvement in environmental quality but also a boost to labour demand. The idea of a „double dividend“ has been discussed extensively in the economic literature. Now, the consensus view among economists seems to be that a green tax reform is unlikely to generate a significant „double dividend", if previous policies have been economically rational and if other distortions in the economy exist. Excellent surveys of the debate are available in Goulder (1995) and Bovenberg (1999). 
$E\left(d \Phi d J_{2}\right)=0$ and $E\left(d J_{1} d J_{2}\right)=0$. Equation (5) and (6) indicate that there are two sources of uncertainty. Type I uncertainty represented by the geometric Brownian motion captures price and/or demand uncertainty. Instability of this type may be helpful in predicting the variability in profits. To understand the policy impact upon labour demand, we have additionally assumed type II uncertainty (represented by the two jump processes). This newly added uncertainty represents political uncertainty about future changes in non-wage labour costs and allows to investigate how uncertainty about future non-wage labour costs alters incentives for employment. In our work, the timing of the potential policy shifts is exogenous. ${ }^{9}$ In other words, our model contains two uncorrelated jumps and the behaviour between the jumps is that of a "Gaussian“ diffusion („Poisson-Gaussian model“). The critical question for the firm is how best to respond in such an uncertain environment. ${ }^{10}$

Using Itô's Lemma, the Bellman equation for the value $V$ at time zero is

$$
\begin{aligned}
r V=\max _{L}\left\{Z\left[\theta K^{-\mu}+(1-\theta) L^{-\mu}\right] \frac{-1}{\mu \psi}-w(1+\tau) L+\eta Z V_{Z}\right. \\
\left.+\frac{1}{2} \sigma^{2} Z^{2} V_{Z Z}+\lambda_{1}\left[V\left(\tau\left(1+\phi_{1}\right)\right)-V\right]-\lambda_{2}\left[V-V\left(\tau\left(1-\phi_{2}\right)\right)\right]\right\}
\end{aligned}
$$

To find the optimal condition for employees with the existence of firing costs and hiring costs, we need to obtain the value of the marginal employed worker first $\left(v=V_{N}\right)$ and then compare the marginal value of employees with the marginal hiring costs and firing costs (variable subscripts denote partial derivatives). We take the derivative of (7) with respect to $L$

$$
r v=Z F(K, L)-w(1+\delta)+\eta Z v_{Z}+\frac{1}{2} \sigma^{2} Z^{2} v_{Z Z}+\lambda_{1}\left[v\left(\tau\left(1+\phi_{1}\right)\right)-v\right]-\lambda_{2}\left[v-v\left(\tau\left(1-\phi_{2}\right)\right)\right]
$$

where $v=V_{N}$ is the value of employing the marginal worker and

$$
F(K, L)=\frac{1-\theta}{\psi} L^{-\mu-1}\left[\theta K^{-\mu}+(1-\theta) L^{-\mu}\right] \frac{-1}{\mu \psi}-1
$$

\footnotetext{
${ }^{9}$ In practical terms, we are not exploring endogenous uncertainty but exogenous uncertainty that may (or may not) be resolved with time but cannot be resolved by action on part of the firm. Alternatively, one can assume endogenous uncertainty. Jumps might be correlated because their amplitudes are drawn from correlated distributions, or because the correlation in the jump times (the jumps may be simultaneous, or have correlated stochastic arrival intensities). This correlated „double-jump“ approach is richer and more complete. A general characterisation of such affine jump -diffusions models is available in Duffie et al. (2000).

${ }^{10}$ Bentolila and Bertola (1990) have developed a dynamic model of labour demand with type I uncertainty, but have not considered policy uncertainty (type II uncertainty).
} 
The solution for $v(Z)$ consists of the particular integral and the complementary function. We first deal with identification of uncertainty effects in the very special case where hiring and firing costs are zero. This special case turns out to be useful as a starting point and for comparisons. Then we turn to the general case with positive hiring and firing costs. In the absence of hiring and firing costs, the particular integral may be expressed as

$$
v^{P}(Z)=E\left[\int_{0}^{\infty}[Z F(K, L)-w(1+\tau)] e^{-r s} d s\right]
$$

which is the expected present value of the marginal employed worker. $E[\cdot]$ denotes the expectation operator given information at initial time $\mathrm{t}=0$. This integral can be rewritten as (a proof is given in Appendix A)

$$
v^{P}(Z)=\frac{Z F(K, L)}{r-\eta}-\frac{w}{r}-\frac{w \tau}{r-\lambda_{1} \phi_{1}+\lambda_{2} \phi_{2}} .
$$

The real discount rate for $Z F(K, L)$ is $r-\eta$ since $Z$ grows at an expected rate of $\eta$. The real wage, $w$, is exogenous and then has a discount rate of $r$. The current value of $\tau$ has a discount rate adjusted by the possibilities of jumps and drops in the future value of $\tau$.

The firm's option value of hiring in the future and its option value of firing once the worker is employed are measured by the complementary function:

$$
r v=\eta Z v_{Z}+\frac{1}{2} \sigma^{2} Z^{2} v_{Z Z}+\lambda_{1}\left[v\left(\tau\left(1+\phi_{1}\right)\right)-v\right]-\lambda_{2}\left[v-v\left(\tau\left(1-\phi_{2}\right)\right)\right]
$$

Letting $v^{G}$ be the value of the option, the general solutions for the hiring and firing options ( $v_{H}^{G}$ and $v_{F}^{G}$ ) have the following forms, respectively (see Appendix $B$ for details),

$$
v_{H}^{G}(Z)=A_{1} Z^{\beta_{1}}
$$

and

$$
v_{F}^{G}(Z)=A_{2} Z^{\beta_{2}}
$$

where $\beta_{1}$ and $\beta_{2}$ are the positive and negative roots of the following characteristic equation: 


$$
\frac{1}{2} \sigma^{2} \beta(\beta-1)+\eta \beta-r=0
$$

To satisfy the boundary conditions that $v_{H}^{G}(0)=0$ and $v_{F}^{G}(\infty)=0$, we use the positive solution for $v_{H}^{G}$ and the negative solution for $v_{F}^{G}$.

We now add fixed marginal hiring $(H)$ and firing $(F)$ costs to the model with both $H$ and $F$ being payable by the firm. ${ }^{11}$ When there are fixed costs of either hiring or firing, the firm will consider the option value of maintaining her current position against the alternative of hiring or firing. In other words, it should be evident that the hiring and firing policy of the optimising firm is discontinuous. In some periods the optimal strategy of the firm will be to adjust the number of workers. Under other demand conditions a wait and see attitude will be chosen. More specifically, employment inaction will always be chosen when deviations of the expected marginal product of labour from the optimal level do not justify the costs of employment adjustment. Hiring and firing costs therefore generate a corridor of inaction (wait and see attitude for the time being) within which firms do not change their workforce. This region is identified by the upper, $Z_{H}$, and lower, $Z_{F}$, control barrier. The definitions of the hiring and firing barriers, $Z_{H}$ and $Z_{F}$, are given by the value-matching and smooth-pasting conditions below. It is straightforward to show that according to the value-matching conditions the firm would find it optimal to exercise its option to hire or fire the marginal worker once $Z$ hits one of the two barriers:

$$
\frac{Z_{H} F(K, L)}{r-\eta}-\frac{w}{r}-\frac{w \tau}{r-\lambda_{1} \phi_{1}+\lambda_{2} \phi_{2}}+A_{2} Z_{H}^{\beta_{2}}=H+A_{1} Z_{H} \beta_{1}
$$

and

$$
-\left[\frac{Z_{F} F(K, L)}{r-\eta}-\frac{w}{r}-\frac{w \delta}{r-\lambda_{1} \phi_{1}+\lambda_{2} \phi_{2}}\right]+A_{1} Z_{F}{ }^{\beta_{1}}=F+A_{2} Z_{F}{ }^{\beta_{2}}
$$

The left-hand sides of (16) and (17) show the marginal benefit from hiring/firing a worker and the right-hand sides the corresponding marginal costs. The marginal benefit of hiring a worker is equal to the sum of the present discounted value of his productivity net of wages and the value of the option to fire him. The firm's ability to fire raises the benefit from employing a worker. The marginal cost of hiring is the sum of the direct hiring costs and the sacrificed option to hire him in the future. By hiring

\footnotetext{
${ }^{11} \mathrm{H}$ can be thought of as representing the screening and training costs associated with the recruitment of a new employee and $F$ as the severance costs imposed by legislation when dismissing an employee.
} 
a worker today, the opportunity to do so in the future - when conditions may be more favourable - is sacrificed. Similarly, by firing a worker, the opportunity to do so in the future - when demand conditions may be even more adverse - is sacrificed, and the opportunity to hire him again is gained. The smooth-pasting conditions ensure that hiring (firing) is not optimal either before nor after the hiring (firing) threshold is reached. In technical terms, this means

$$
\frac{F(K, L)}{r-\eta}+A_{2} \beta_{2} Z_{H}^{\beta_{2}-1}=A_{1} \beta_{1} Z_{H}^{\beta_{1}-1}
$$

and

$$
-\frac{F(K, L)}{r-\eta}+A_{1} \beta_{1} Z_{F}{ }^{\beta_{1}-1}=A_{2} \beta_{2} Z_{F}{ }^{\beta_{2}-1}
$$

Equations (16) - (19) form a non-linear system of equations with four unknown parameters, $Z_{H}, Z_{F}, A_{1}$, and $A_{2}$, and can be solved for numerically once the solutions for $\beta_{1}$ and $\beta_{2}$ are obtained from (15). In order to visualise our approach to employment determination, we next consider calibrations of the model. These make the model amenable to graphical analysis.

\section{Calibration and Results}

The preceding section has laid out the model economy. Having illustrated that the stochastic framework has important ramifications for the dynamic behaviour of labour demand, we proceed in this section to use the theoretical models derived above to carry out a number of simulations to shed light on the workings of the models and the economic forces at work. ${ }^{12}$ For this reason, the model is calibrated in order to match characteristics of the German economy. In other words, an intuitive interpretation of the model is provided, and throughout the remainder of the paper no background in stochastic calculus is necessary to understand the arguments in the text.

The unit time length corresponds to one year. Our base parameters are $\sigma=0.15, \eta=0.0, \lambda_{1}=0.1$, $\lambda_{2}=0.1, \phi_{1}=0.1, \phi_{2}=0.1, K=1, r=0.04, w=1, H=0.1, F=0.6, \Psi=1.5, \mu=0.4825, \theta=0.3$, and $\tau$ $=0.75$. Where possible, parameter values are drawn from empirical labour studies. The firing and hiring parameters are consistent with those in Bertolila and Bertola (1990) for Germany. Their estimated firing costs for Germany are in the range $0.562 \leq F \leq 0.750$ and their hiring cost estimate (excluding on-the-job-training) for Germany is 0.066 of the average annual wage. Our specification ( $H$ 
$=0.10$ ) is also broadly consistent with the recruiting and training cost of two months in Mortenson and Pissarides' (1999) calibration. ${ }^{13}$ They suggest that this number is consistent with survey results reported in Hamermesh (1993). The elasticity of substitution between capital and labour $1 /(1+\mu)=0.7$ has been taken from Pissarides (1998). Point estimates for $\tau$ have been derived from Table 1 and 3 . Finally, the price elasticity of demand parameter is set at $\Psi=1.50$ as in Bovenberg et al. (1998). The determination of some parameters, however, requires the use of judgement, i.e. they reflect a back-ofthe-envelope calculation. ${ }^{14}$

To motivate the analysis of policy uncertainty, special attention has to be paid to the calibration of the Poisson processes. The Poisson process implies that the likelihood of a policy change is determined by the arrival rate $\lambda$. This means that the time $t$ one has to wait for the switch event to occur is a random variable whose distribution is exponential with parameter $\lambda$ :

$$
F(t) \equiv \text { prob }\{\text { event occurs before } t\}=1-e^{-\lambda t}
$$

The corresponding probability density is

$$
f(t) \equiv F^{\prime}(t)=\lambda e^{-\lambda t}
$$

In other words, the probability that the event will occur sometime within the short interval between $t_{0}$ and $t_{0}+d t$ is approximately $\lambda e^{-\lambda t} d t$. In particular, the probability that it will occur within $d t$ from now (when $t=0$ ) is approximately $\lambda d t$. In this sense $\lambda$ is the probability per unit of time. Moreover, the number of policy changes $(x)$ that will take place over any interval of length $\Delta$ is distributed according to the Poisson distribution

$$
g(x) \equiv \operatorname{prob}\{x \text { event occur }\}=\frac{(\lambda \Delta)^{x} e^{-\lambda \Delta}}{x !}
$$

\footnotetext{
12 The numerical computation of the trigger points is less complex than one would think. The numerical boundary value problem is solved with the method of Newton-Raphson for nonlinear systems. For a description of the algorithm used to compute the numerical simulations, see Press et al. (2002).

${ }^{13}$ Firing costs have increased substantially in Germany in the late 1960s and 1970s and have roughly stayed on this high level since then [see, Caballero and Hammour (1997)]. The OECD (1999) has compiled a comprehensive dataset describing legislative firing (procedural requirements, notification periods, severance pay, special requirements for collective dismissals, and short-time work schemes) and hiring (rules favouring disadvantaged groups, conditions for temporary and fixed-term contracts, training requirments) costs covering 22 indicators for 27 countries. These 22 indicators provide the inputs for the construction of cardinal summary indicators of employment protection across countrties. These indicators of strictness of employment protection in the late 1990s are also available in the DICE database (for further details, see www.cesifo.de).

${ }^{14}$ Note, however, that the goal of this paper is not to derive precise quantitative estimates of the impact of various labour market regulations, but rather to illustrate the qualitative predictions of a partial equilibrium model and to identify key features of the framework in determining the policy's quantitative impact.
} 
whose expected value is the arrival rate times the length of the interval $\lambda \Delta$. We can back out from equation (22) the agent's beliefs about policy changes. As a guide to calibration, Table 4 below provides the probabilities that either one $(x=1)$ or three $(x=3)$ jumps will occur within 5 years $(\Delta=$ 5 ) or 10 years $(\Delta=10)$ for the four arrival rates $\lambda=0.01, \lambda=0.05, \lambda=0.10$ and $\lambda=0.15$, respectively. For example, for $\lambda=0.05$ the probability that one jump will occur within 5 years is 19.5 percent.

Table 4: Jump Probabilities for the Poisson Process

\begin{tabular}{|l|l|l|l|l|}
\hline \multicolumn{2}{|c|}{$\lambda=\mathbf{0 . 0 1}$} & $\lambda=\mathbf{0 . 0 5}$ & $\lambda=\mathbf{0 . 1 0}$ & $\lambda=\mathbf{0 . 1 5}$ \\
\hline prob $\{1$ event in 5 years $\}$ & 0.048 & 0.195 & 0.303 & 0.354 \\
\hline prob $\{3$ events in 5 years $\}$ & 0.000002 & 0.002 & 0.013 & 0.033 \\
\hline $\operatorname{prob}\{1$ event in 10 years $\}$ & 0.090 & 0.303 & 0.368 & 0.395 \\
\hline $\operatorname{prob}\{3$ events in 10 years $\}$ & 0.0001 & 0.012 & 0.061 & 0.126 \\
\hline
\end{tabular}

Given the high probability of increasing non-wage labour costs in Germany, a sensitivity analysis is performed over the grid $\lambda_{i} \in\{0.0,0.2\}$ for $i=1,2$.

Figure 1: The Employment Thresholds for Alternative Hiring and Firing Costs
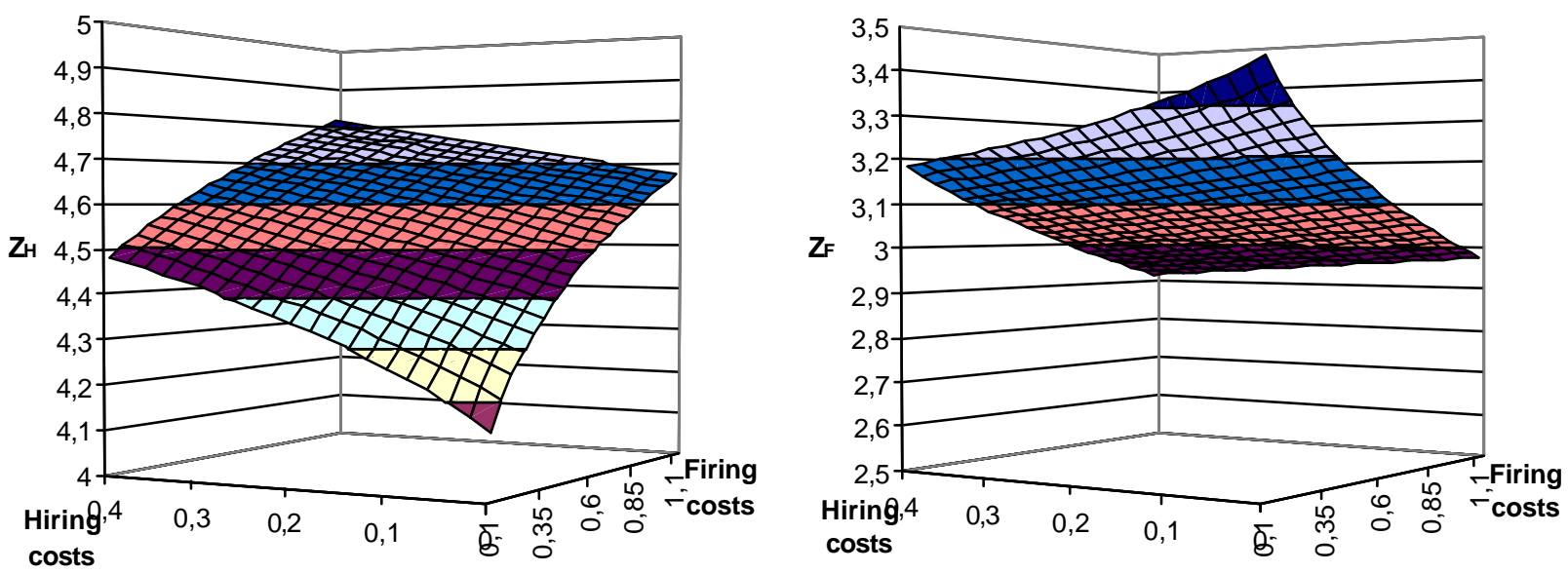

First, we consider a policy which changes hiring and firing costs. Despite the fact that liberalisation of labour markets has ranked highly in European policy debates, few effective changes to the stringent nature of the employment constraints facing European firms appear to have been implemented over the last decade. Moreover, in a number of European countries the general trend towards greater employment protection would actually appear to have continued. The numerical results are given in Figure 1. The major result of the calibrations is that higher hiring and firing costs lead to an increase of the no action area, i.e. increasing hiring and/or firing increases the hiring threshold $\left(Z_{H}\right)$ and decreases the firing threshold $\left(Z_{F}\right)$. The net impact upon employment turns out to be negative because the hiring 
thresholds are steeper, compared to the firing ones. This asymmetric widening of the region of inaction implies that German unemployment is caused not so much by an increased probability of loosing one's job, but rather by a reduction in the probability of finding a job when one is unemployed. ${ }^{15}$

Figure 2: The Impact of the Level of Non-Wage Labour Costs Upon the Thresholds

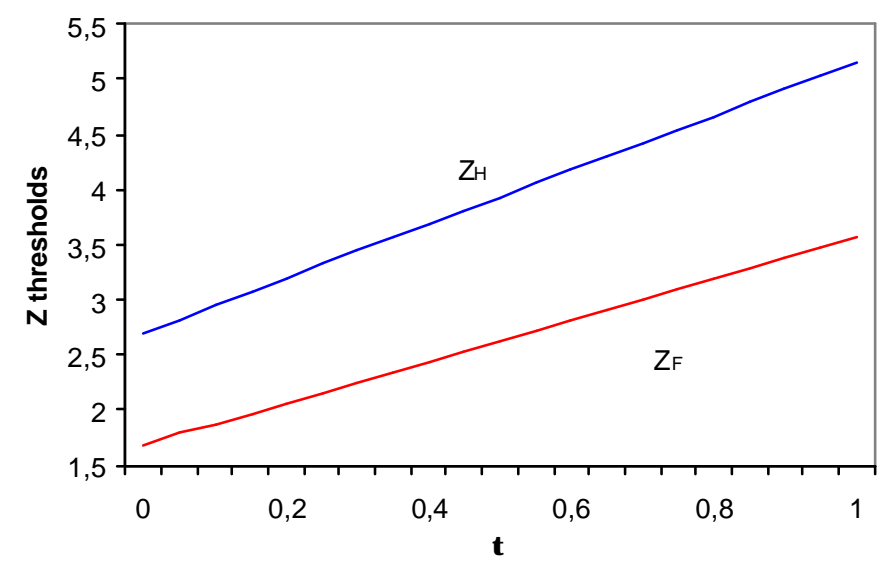

Figure 2 investigates numerically the impact of higher non-wage costs levels. The graph clearly indicates that a higher share of non-wage labour costs $(\tau)$ leads to an increase of $Z_{H}$ and $Z_{F}$ and a widening of the wait and see area.

Figure 3 provides a sensitivity analysis of the thresholds with respect to $\lambda_{1}$ and $\lambda_{2}$, i.e. we illustrate the impact of uncertainty about future non-wage labour costs upon the optimal hiring and firing thresholds. Alternatively, one may say that we consider different degrees of „,policy-jumpiness“. The 3-D graphs clearly indicate the entire no-action areas. If $\lambda_{I}$ increases, then the $Z_{H}$ investment threshold will rise - firms will be more reluctant to hire to avoid getting caught with too much workers, should the future turn out worse than expected. By contrast, if the future turns out better than expected, the firm can just hire more workers as needed. The implication is that the textbook net present value rule is blantly inappropriate in any context other than the unrealistic setting where sunk costs are negligible and there is certainty regarding the determinants of the profitability of the project to be undertaken. On the contrary, if $\lambda_{2}$ increases, then the $Z_{H}$ threshold declines. In other words, uncertainty about future non-wage labour costs pushes up the real option "price" and increases the advantages to the firm of

\footnotetext{
15 This feature is consistent with the empirical evidence in Bean (1994), p. 576. More indirectly, countries where employment is protected tend also to discourage business start-ups. Fonseca st al. (2001) have shown that impediments to firm formation are strongly and negatively correlated with the employment to population ratio. This leads to the ,all or nothing“" warning issued by Coe and Snower (1997). They argue that piecemeal labour market reforms may have had so little success because they disregarded the complementarities between a braod range of policies and institutions. Hence, what is needed is a fundamental labour market reform which is both broad and deep.
} 
waiting. The theory therefore explains why firms often respond slowly to changes in policy variables all of which, orthodox theory suggests, should elicit an instant response. ${ }^{16}$

Figure 3: The Impact of $\lambda_{1}$ and $\lambda_{2}$ Upon the Thresholds
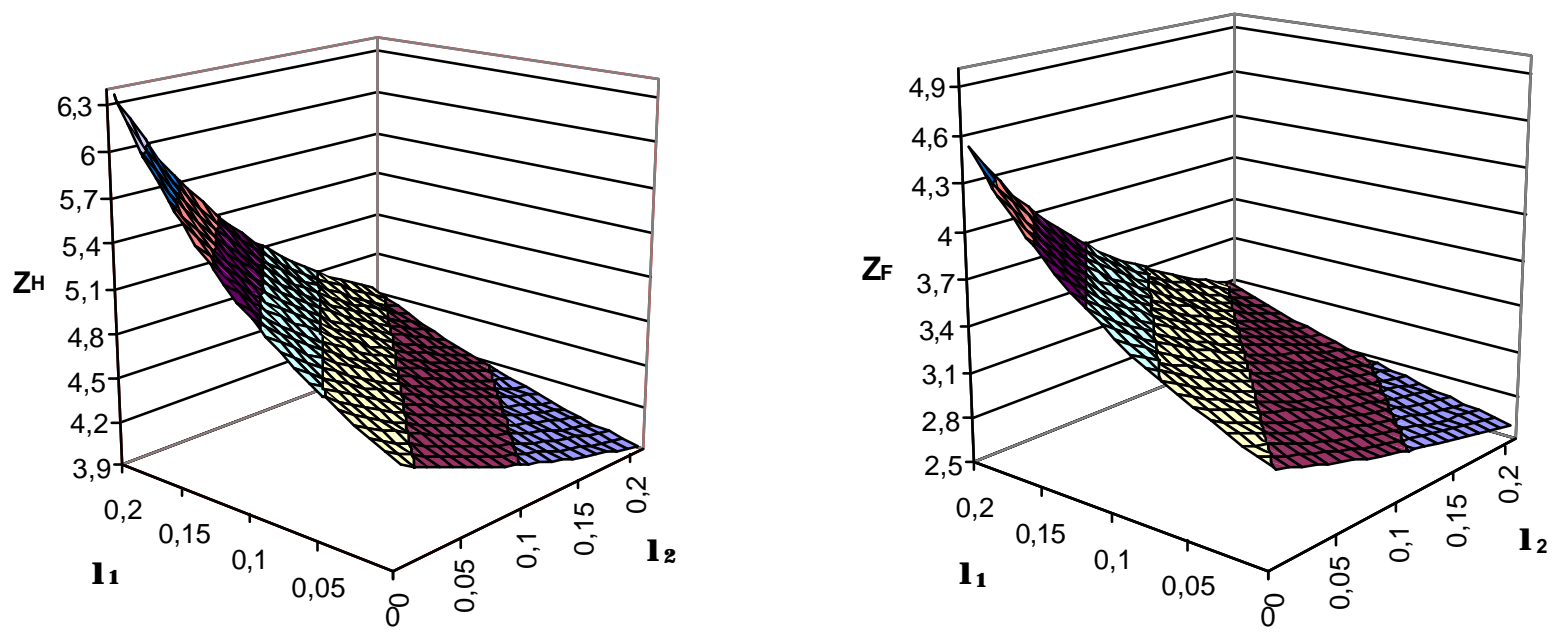

Figure 4: The Threshold Values as a Function of $\phi_{1}$

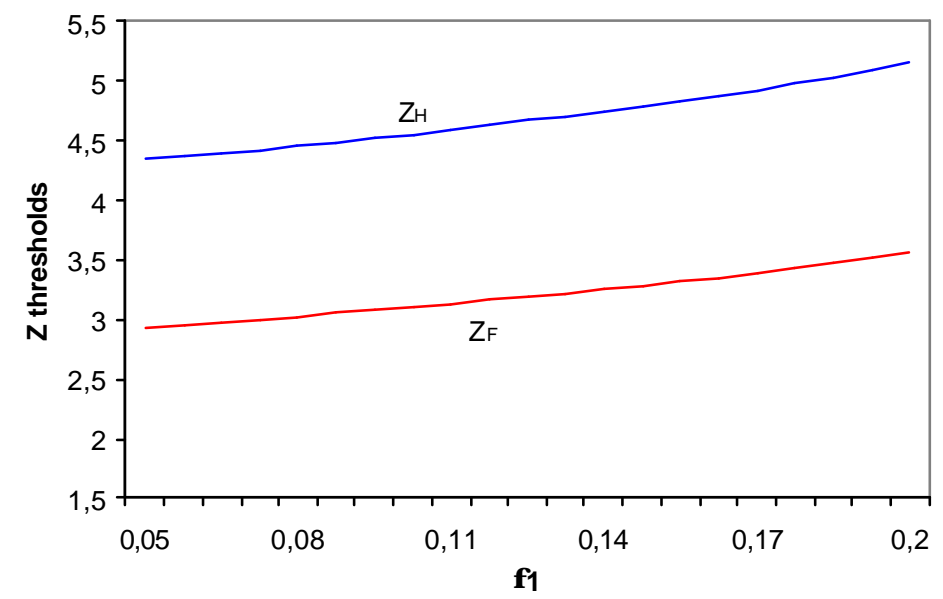

Figure 4 shows how the magnitude of the jumps (represented by $\phi_{1}$ ) affects the thresholds. Two main messages emerge from Figure 4. The first concerns the hiring and firing thresholds: The simulations suggest that perceived upside risks act as an important deterrent to hirings and firings. Pari passu, an unreliable political environment system translates into higher thresholds and hence lowers the efficiency of the economy.

\footnotetext{
${ }^{16}$ When real options are such a useful and powerful tool, why haven't they been more widely adopted? The main reason probably is that real options are rather difficult to explain - it's a daunting task to communicate them effectively.
} 
Let us now consider changes in $\sigma$. In other words, we analyse the sensitivity of the optimal thresholds with respect to changes in the volatility of the geometric Brownian motion representing demand and/or price uncertainty. As in the existing literature, we find that the threshold value at which hiring takes place is increasing in the "noisiness" level even though the firm is risk neutral. In volatile environments, the best tactic is to keep options open and await new information rather than commit an employment decision today. The intuition is that the firm can counteract the impact from additional uncertainty by a wait and see attitude for the time being.

Figure 5: The Threshold Values as Function of $\sigma$

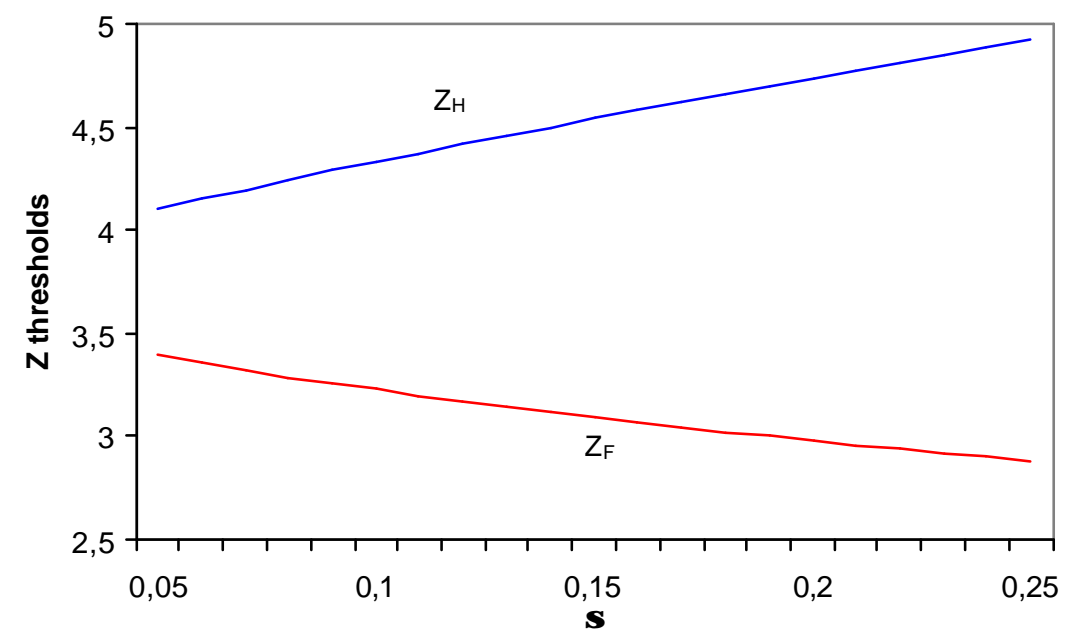

Figure 6: The Impact of $\tau$ Upon the Labour Demand Curve

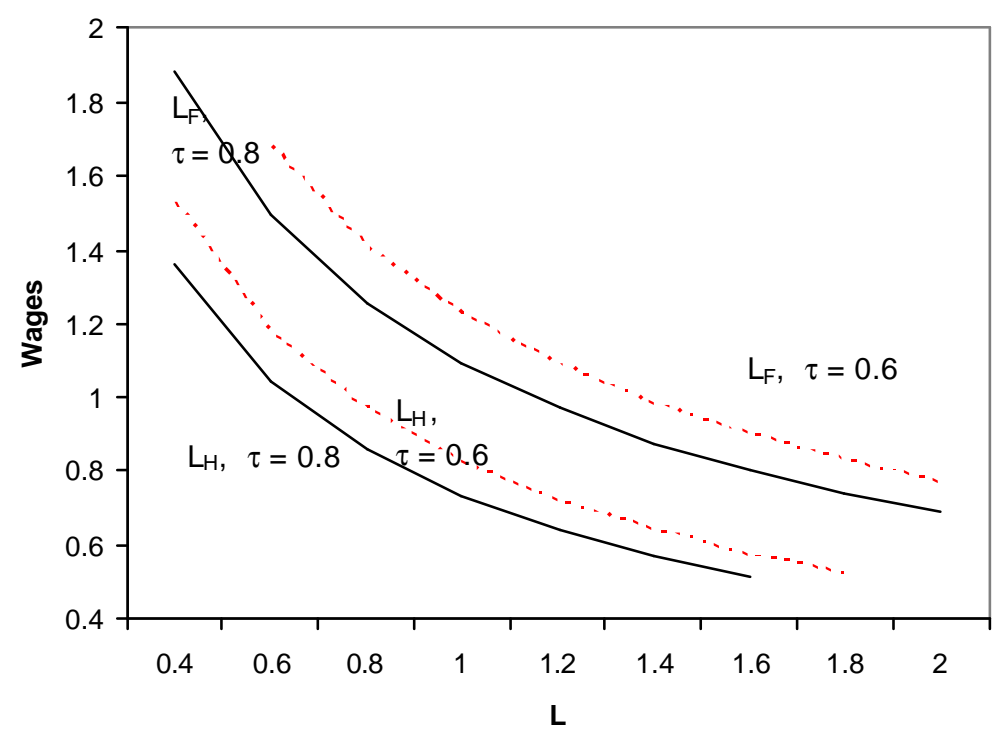

In order to gain additional insight into the model, Figure 6 shows how non-wage labour costs affect the labour demand schedule. We investigate $\tau=0.8$ and $\tau=0.6$. For each parameterisation, the hiring 
and firing employment thresholds are derived for $Z=3.5$ with the fact that marginal value of employees from particular solutions are the same with $Z$ and $L$ thresholds. The firm would hire a marginal worker if the employment falls below $L_{H}$; and the firm would fire a marginal employee if the employment level is more than $L_{F}$. The comparison of the curves reveals that higher non-wage labour costs reduce labour demand. This again highlights the interdependencies between labour markets and a social security system which is tied to employment.

\section{Summary Remarks and Conclusions}

Germany has one of the highest unemployment rates - $11 . \%$ or 4.5 million people - in the rich world. ${ }^{17}$ Against this gloomy background, chancellor Schröder and his government have taken some encouraging steps in their "Agenda 2010". Most strikingly they have proposed substantial cuts in the duration and amounts of unemployment and non-wage labour costs (sickness benefits). The government has also suggested ways that would weaken job-protection in small companies and encourage employers to hire new workers. ${ }^{18}$ In detail, the government has agreed to make firing rules more flexible by letting small firms take on a sixth worker - or more - on a fixed-term contract without the other employees becoming eligible for full job protection. In larger firms, the government proposes offering anyone laid off a choice between a fixed amount of compensation, not automatically available at present, and seeking redress in the courts, in which case the worker would have to renounce all rights to financial compensation. This procedure would help to avoid the long, unpredictable and costly legal proceedings that always follow any attempt to lay off workers in Germany. Furthermore, the government says it will encourage wage bargaining at the company level by making it easier for firms to opt out of the straitjacket of sector-wide agreements when circumstances so require. Above all, the government is determined to reduce the non-wage costs of labour. Of course, the model developed in this paper is stylised and may not capture all of the detail. Nevertheless, the modelling exercise clearly indicates that such a reform package - if boldly and fully implemented - will push Germany in the right direction. ${ }^{19}$

\footnotetext{
17 Germany's labour market institutions have by and large been kept unchanged over the last thirty years. Therefore, their interaction with changes in the economic environment is the most plausible 1candidate for explaining rising unemployment. Economic conditions have become more volatile over the last ten years due to globalisation and the transition to the new economy. This explanations is in fact the gist of papers by Blanchard and Wolfers (2000), Chen et al. (2002) and Ljungqvist and Sargent (2002).

${ }^{18}$ In the run-up to the general elections in September 2002, the German government has shown itself still less reform-minded. For instance, the new regulations on worker participation in shop-floor decision making mean greater bureaucratic outlays and less flexibility in decision making.

${ }_{19}$ However, it is crucial to recognise that Germany is in fact stuck in a web of anti-competitive rigidities which involve all markets. Recent research suggests that policies enhancing product market competition contribute to higher output and employment growth over the medium to longer term. While it is recognised that the structural reforms necessary to enhance product market competition may entail short-term dislocation of labour, over the longer run these policies will reduce monopolistic tendencies, weaken insider-outsider mechanisms and there by
} 


\section{Appendix A: Derivation of Equation (11)}

Assume that the particular solution for the shadow price of employees has the following functional form as the particular integral components:

(A1) $\quad v=B Z F(K, L)+C w+D w \tau$.

Then, we have

(A2) $\eta Z v_{Z}=\eta B Z F(K, L)$,

(A3) $v_{Z Z}=0$

(A4) $\lambda_{1}\left[v\left(\tau\left(1+\phi_{1}\right)\right)-v\right]=\lambda_{1} D w \tau \phi_{1}$,

(A5) $\quad \lambda_{2}\left[v-v\left(\tau\left(1-\phi_{2}\right)\right)\right]=\lambda_{2} D w \tau \phi_{2}$.

Substituting into equation (8) yields

$$
\begin{aligned}
& r(B Z F(K, L)+C w+D w \tau)=Z F(K, L, N)-w(1+\tau)+\eta B Z F(K, L)+\lambda_{1} D w \tau \phi_{1} . \\
& -\lambda_{2} D w \tau \phi_{2}
\end{aligned}
$$

Rearranging and collecting terms yields

$$
Z F(K, L)[(r-\eta) B-1]+w[r C+1]+w \tau\left[\left(r-\lambda_{1} \phi_{1}+\lambda_{2} \phi_{2}\right) D+1\right]=0 .
$$

Equation (A8) must hold for any value of $B, C$, and $D$, so that

(A8) $B=\frac{1}{r-\eta}$,

(A9) $C=\frac{-1}{r}$,

(A10) $D=\frac{-1}{r-\lambda_{1} \phi_{1}+\lambda_{2} \phi_{2}}$

It is then straightforward to obtain equation (11).

\section{Appendix B: Derivation of Equations (13) and (14)}

The homogeneous solutions to equation (12) should have the same components as the particular solutions. Assume the homogeneous solutions have the functional form

(B1) $v=A Z^{\beta}+B \tau+C$.

Then we have

lead to higher levels of overall employment. At the same time, such an institutional setting should also contribute to a more innovative and dynamic economy by thriving entrepreneurial activity [Acemoglu et al. (2002)]. 
(B2) $\eta Z v_{Z}=\eta \beta A Z^{\beta}$,

(B3) $\frac{1}{2} \sigma^{2} Z^{2} v_{Z Z}=\frac{1}{2} \sigma^{2} \beta(\beta-1) A Z^{\beta}$,

(B4) $\quad \lambda_{1}\left[v\left(\tau\left(1+\phi_{1}\right)\right)-v\right]=\lambda_{1} B \tau \phi_{1}$,

(B5) $\quad \lambda_{2}\left[v-v\left(\tau\left(1-\phi_{2}\right)\right)\right]=\lambda_{2} B \tau \phi_{2}$,

Now substitute into equation (12) in the text. It is straightforward to obtain the following characteristic equation:

$$
r\left(A Z^{\beta}+B \tau+C\right)=\eta \beta A Z^{\beta}+\frac{1}{2} \sigma^{2} \beta(\beta-1) A Z^{\beta}+\lambda_{1} B \tau \phi_{1}-\lambda_{2} B \tau \phi_{2}
$$

Rearranging and collecting terms yields

(B7) $\left(\frac{1}{2} \sigma^{2} \beta(\beta-1) r+\eta \beta-r\right) A Z^{\beta}-r(B \tau+C)+\lambda_{1} B \tau \phi_{1}-\lambda_{2} B \tau \phi_{2}=0$

Equation (B7) must hold for any value of $A, B$, and $C$. Thus, we have

(B8) $\quad \frac{1}{2} \sigma^{2} \beta(\beta-1)+\eta \beta-r=0$

(B9) $\quad r(B \tau+C)=\lambda_{1} B \tau \phi_{1}-\lambda_{2} B \tau \phi_{2}$

Note that (B9) would generate the same solutions as part of particular solutions with the value of $C=-w \tau / r$. Therefore only equation (B8) consists of homogenous solutions. Note that there are two roots for characteristic equation (B8). Therefore, the general solutions are denoted by

(B10) $v^{G}=A_{1} Z^{\beta_{1}}+A_{2} Z^{\beta_{2}}$,

where $\beta_{1}>0$ and $\beta_{2}<0$. 


\section{References:}

Abel, A.B. and J.C. Eberly (1994) “A Unified Model of Investment Under Uncertainty", American Economic Review 84, 1369-1384.

Acemoglu, D., Aghion, P. and F. Zilibotti (2002) "Distance to Frontier, Selection, and Economic Growth", NBER Working Paper No. 9066, Cambridge (Mass.).

Amran, M. and N. Kulatilaka (1999) Real Options: Managing Strategic Investment in an Uncertain World, Boston (Harvard Business School Press).

Bean, C.R. (1994) "European Unemployment: A Survey", Journal of Economic Literature 32, 573619.

Bentolila, S. and G. Bertola (1990) "Firing Costs and Labor Demand: How Bad is Eurosclerosis?", Review of Economic Studies 57, 381-402.

Blanchard, O. and J. Wolfers (2000) "The Role of Shocks and Institutions in the Rise of European Unemployment: The Aggregate Evidence”, The Economic Journal 110, C1-C33.

Bovenberg, A.L. (1999) "Green Tax Reforms and the Double Dividend: An Updated Reader's Guide", International Tax and Public Policy 6, 421-443.

Bovenberg, A.L., J.J. Graafland and R.A. de Mooij (1998) Tax Reform and the Dutch Labor Market: An Applied General Equlibrium Approach, CPB Netherlands Bureau for Economic Policy Analysis, Research Memorandum 143, The Hague.

Caballero, R. and M. Hammour (1997) "Jobless Growth: Appropriability, Factor Substitution, and Unemployment", NBER Working Paper No. 6221, Cambridge (Mass.).

Calmfors, L. and J. Driffill (1988) „Bargaining Structure, Corporatism and Macroeconomic Performance“, Economic Policy, No. 3, 13-61.

Chen, Y.-F., Snower, D. and G. Zoega (2002) "Labour Market Institutions and Macroeconomic Shocks", CEPR Discussion Paper No. 3480, London.

Coe, D. and D.J. Snower (1997) „Policy Complementarities: The Case for Fundamental Labour Market Reform“, IMF Staff Papers 44, 1-35.

Copeland, T. and V. Antikarov (2001) Real Options - A Practitioner's Guide, London (Texere Publishing).

Coy, R. (1999) „Exploiting Uncertainty: The RealOptions Revolution in Decision Making“, Business Week, June 7, 118-124.

Dixit, A. and R. Pindyck (1994) Investment Under Uncertainty, Princeton (Princeton University Press).

Duffie, D., Pan, J. and K. Singleton (2000) „Transform Analysis and Asset Pricing for Affine Jump Diffusions“, Econometrica 68, 1343-1376.

Forseca, R., Lopez-Gardia, P. and C. Pissarides (2001) "Entrepreneurship, Start-Up Costs and Employment", European Economic Review 45, 692-705. 
Goulder, L. (1995) "Environmental Taxation and the Double Dividend: A Reader's Guide", International Tax and Public Finance 2, 157-183.

Hamermesh, D.S. (1993) Labor Demand, Princeton (Princeton University Press).

Lander, D.M. and G.E. Pinches (1998) "Challenges to the Practical Implementation of Modeling and Valuing Real Options", Quarterly Review of Economics and Finance 38, 537-567.

Ljungqvist, L. and T. Sargent (2002) “The European Unemployment Experience”, CEPR Discussion Paper No. 3543, London.

Minford, P. and R. Naraidoo (2002) "Vicious and Virtuous Circles - The Political Economy of Unemployment”, CEPR Discussion Paper No. 3618, London.

Mortenson, D.T. and C.A. Pissarides (1999) "New Developments in Models of Search in the Labor Market", in: Ashenfelter, O.C. and D. Card (eds.) Handbook of Labor Economics Vol. 3B, 2567-2627 Amsterdam (Elsevier Science).

OECD (1999) Employment Outlook, Paris.

Pissarides, C. (1998) "The Impact of Employment Tax Cuts on Unemployment and Wages: The Role of Unemployment Benefits and Tax Structure", European Economic Review 42, 155-183.

Press, W.H., Teukolsky, S.A., Vetterling, W.T. and B.P. Flannery (2002) Numerical Recipes in C++: The Art of Scientific Computing, $2^{\text {nd }}$ edition, Cambridge (Cambridge University Press).

Schröder, C. (2002a) "Personalzusatzkosten in der deutschen Wirtschaft", iw-trends 29, Nr. 1, 40-46.

Schröder, C. (2002b) "Industrielle Arbeitskosten im internationalen Vergleich", iw-trends 29, Nr. 2, 115. 


\title{
CESifo Working Paper Series
}

\author{
(for full list see www.cesifo.de)
}

888 Bernard Steunenberg, Coordinating Sectoral Policymaking: Searching for Countervailing Mechanisms in the EU Legislative Process, March 2003

889 Eytan Sheshinski, Optimum Delayed Retirement Credit, March 2003

890 Frederick van der Ploeg, Rolling Back the Public Sector - Differential effects on employment, investment and growth, March 2003

891 Paul De Grauwe and Marc-Alexandre Sénégas, Monetary Policy in EMU when the Transmission is Asymmetric and Uncertain, March 2003

892 Steffen Huck and Kai A. Konrad, Strategic Trade Policy and the Home Bias in Firm Ownership Structure, March 2003

893 Harry Flam, Turkey and the EU: Politics and Economics of Accession, March 2003

894 Mathias Hoffmann and Ronald MacDonald, A Re-examination of the Link between Real Exchange Rates and Real Interest Rate Differentials, March 2003

895 Badi H. Baltagi, Espen Bratberg, and Tor Helge Holmås, A Panel Data Study of Physicians' Labor Supply: The Case of Norway, March 2003

896 Dennis C. Mueller, Rights and Citizenship in the European Union, March 2003

897 Jeremy Edwards, Gains from Trade in Tax Revenue and the Efficiency Case for Trade Taxes, March 2003

898 Rainer Fehn and Thomas Fuchs, Capital Market Institutions and Venture Capital: Do They Affect Unemployment and Labour Demand?, March 2003

899 Ronald MacDonald and Cezary Wójcik, Catching Up: The Role of Demand, Supply and Regulated Price Effects on the Real Exchange Rates of Four Accession Countries, March 2003

900 R. Selten, M. Schreckenberg, T. Pitz, T. Chmura, and S. Kube, Experiments and Simulations on Day-to-Day Route Choice-Behaviour, April 2003

901 Stergios Skaperdas, Restraining the Genuine Homo Economicus: Why the Economy Cannot be Divorced from its Governance, April 2003

902 Yin-Wong Cheung, Menzie D. Chinn, and Antonio Garcia Pascual, What Do We Know about Recent Exchange Rate Models? In-Sample Fit and Out-of-Sample Performance Evaluated, April 2003 
903 Mika Widgrén, Enlargements and the Principles of Designing EU - Decision-Making Procedures, April 2003

904 Phornchanok Cumperayot, Dusting off the Perception of Risk and Returns in FOREX Markets, April 2003

905 Kai A Konrad, Inverse Campaigning, April 2003

906 Lars P. Feld and Stefan Voigt, Economic Growth and Judicial Independence: Cross Country Evidence Using a New Set of Indicators, April 2003

907 Giuseppe Bertola and Pietro Garibaldi, The Structure and History of Italian Unemployment, April 2003

908 Robert A.J. Dur and Otto H. Swank, Producing and Manipulating Information, April 2003

909 Christian Gollier, Collective Risk-Taking Decisions with Heterogeneous Beliefs, April 2003

910 Alexander F Wagner, Mathias Dufour, and Friedrich Schneider, Satisfaction not Guaranteed - Institutions and Satisfaction with Democracy in Western Europe, April 2003

911 Ngo Van Long, Raymond Riezman, and Antoine Soubeyran, Trade, Wage Gaps, and Specific Human Capital Accumulation, April 2003

912 Andrea Goldstein, Privatization in Italy 1993-2002: Goals, Institutions, Outcomes, and Outstanding Issues, April 2003

913 Rajshri Jayaraman and Mandar Oak, The Signaling Role of Municipal Currencies in Local Development, April 2003

914 Volker Grossmann, Managerial Job Assignment and Imperfect Competition in Asymmetric Equilibrium, April 2003

915 Christian Gollier and Richard Zeckhauser, Collective Investment Decision Making with Heterogeneous Time Preferences, April 2003

916 Thomas Moutos and William Scarth, Some Macroeconomic Consequences of Basic Income and Employment Subsidies, April 2003

917 Jan C. van Ours, Has the Dutch Miracle Come to an End?, April 2003

918 Bertil Holmlund, The Rise and Fall of Swedish Unemployment, April 2003

919 Bernd Huber and Marco Runkel, Optimal Design of Intergovernmental Grants under Asymmetric Information, April 2003

920 Klaus Wälde, Endogenous Business Cycles and Growth, April 2003 
921 Ramon Castillo and Stergios Skaperdas, All in the Family or Public? Law and Appropriative Costs as Determinants of Ownership Structure, April 2003

922 Peter Fredriksson and Bertil Holmlund, Improving Incentives in Unemployment Insurance: A Review of Recent Research, April 2003

923 Bernard M.S. van Praag and Adam S. Booij, Risk Aversion and the Subjective Time Discount Rate: A Joint Approach, April 2003

924 Yin-Wong Cheung, Kon S. Lai, and Michael Bergman, Dissecting the PPP Puzzle: The Unconventional Roles of Nominal Exchange Rate and Price Adjustment, April 2003

925 Ugo Trivellato and Anna Giraldo, Assessing the 'Choosiness' of Job Seekers. An Exploratory Approach and Evidence for Italy, April 2003

926 Rudi Dornbusch and Stanley Fischer, International Financial Crises, April 2003

927 David-Jan Jansen and Jakob de Haan, Statements of ECB Officials and their Effect on the Level and Volatility of the Euro-Dollar Exchange Rate, April 2003

928 Mario Jametti and Thomas von Ungern-Sternberg, Assessing the Efficiency of an Insurance Provider - A Measurement Error Approach, April 2003

929 Paolo M. Panteghini and Guttorm Schjelderup, Competing for Foreign Direct Investments: A Real Options Approach, April 2003

930 Ansgar Belke, Rainer Fehn, and Neil Foster, Does Venture Capital Investment Spur Employment Growth?, April 2003

931 Assar Lindbeck, Sten Nyberg, and Jörgen W. Weibull, Social Norms and Welfare State Dynamics, April 2003

932 Myrna Wooders and Ben Zissimos, Hotelling Tax Competition, April 2003

933 Torben M. Andersen, From Excess to Shortage - Recent Developments in the Danish Labour Market, April 2003

934 Paolo M. Panteghini and Carlo Scarpa, Irreversible Investments and Regulatory Risk, April 2003

935 Henrik Jacobsen Kleven and Claus Thustrup Kreiner, The Marginal Cost of Public Funds in OECD Countries. Hours of Work Versus Labor Force Participation, April 2003

936 Klaus Adam, George W. Evans, and Seppo Honkapohja, Are Stationary Hyperinflation Paths Learnable?, April 2003

937 Ulrich Hange, Education Policy and Mobility: Some Basic Results, May 2003

938 Sören Blomquist and Vidar Christiansen, Is there a Case for Public Provision of Private Goods if Preferences are Heterogeneous? An Example with Day Care, May 2003 
939 Hendrik Jürges, Kerstin Schneider, and Felix Büchel, The Effect of Central Exit Examinations on Student Achievement: Quasi-experimental Evidence from TIMSS Germany, May 2003

940 Samuel Bentolila and Juan F. Jimeno, Spanish Unemployment: The End of the Wild Ride?, May 2003

941 Thorsten Bayindir-Upmann and Anke Gerber, The Kalai-Smorodinsky Solution in Labor-Market Negotiations, May 2003

942 Ronnie Schöb, Workfare and Trade Unions: Labor Market Repercussions of Welfare Reform, May 2003

943 Marko Köthenbürger, Tax Competition in a Fiscal Union with Decentralized Leadership, May 2003

944 Albert Banal-Estañol, Inés Macho-Stadler, and Jo Seldeslachts, Mergers, Investment Decisions and Internal Organisation, May 2003

945 Kaniska Dam and David Pérez-Castrillo, The Principal-Agent Matching Market, May 2003

946 Ronnie Schöb, The Double Dividend Hypothesis of Environmental Taxes: A Survey, May 2003

947 Erkki Koskela and Mikko Puhakka, Stabilizing Competitive Cycles with Distortionary Taxation, May 2003

948 Steffen Huck and Kai A. Konrad, Strategic Trade Policy and Merger Profitability, May 2003

949 Frederick van der Ploeg, Beyond the Dogma of the Fixed Book Price Agreement, May 2003

950 Thomas Eichner and Rüdiger Pethig, A Microfoundation of Predator-Prey Dynamics, May 2003

951 Burkhard Heer and Bernd Süssmuth, Cold Progression and its Effects on Income Distribution, May 2003

952 Yu-Fu Chen and Michael Funke, Labour Demand in Germany: An Assessment of NonWage Labour Costs, May 2003 